\title{
HUBUNGAN ANTARA KECERDASAN EMOSIONAL DENGAN MOTIVASI BELAJAR PADA MAHASISWA
}

\author{
Basri $^{1}$, Fauzi Aldina ${ }^{2}$ \\ ${ }^{1,2}$ Program Studi Bimbingan Konseling Fakultas Keguruan dan Ilmu Pendidikan
}

\begin{abstract}
ABSTRAK
Penelitain ini bertujuan untuk mengetahui hubungan antara kecerdasan emosional dengan motivasi belajar pada mahasisa bimbingan dan konseling Universitas Jabal Ghafur. Penelitian ini menggunakan teknik analisis korelasi Pearson product Momentdengan teknik pengambilan sampel menggunakan Purposive Sampling. Subjek penelitian adalah mahasiswa Bimbingan Konseling Universitas Jabal Ghafur denagn jumlah sampel 79 mahasiswsa. Berdasarkan hasil analisis data menunjukkan terdapat hubungan yang positif yang sangat signifikan antara kecerdasan emosional dengan motivasi belajar , dimana $r x y=0,555 ; p=0,000$ ( $p$ [ 0,050 ). Hasil penelitian menunjukkan mahasisa bimbingan konseling Universitas Jabal Ghafur memiliki kecerdasan emosional yang tergolong tinggi, sebab nilai rerata empirik 97, 354 selisihnya dengan nilai rerata hipotetik 77,5 melebihi bilangan SD atau SB sebesar 8, 184, sedangkan motivasi belajar mahasiswsa tergolong tinggi sebab nilai rerata empirik 135, 658 selisinya dengan nilai rerata hipotetik 110 melebihi bilangan SD atau SB sebesar 11, 613.
\end{abstract}

Kata kunci: Motivasi Belajar, Kecerdasan Emosional, mahasisa Bimbingan dan Konseling.

\section{PENDAHULUAN}

Perkuliahaan merupakan suatu masa yang penuh tantangan dan kesukaran, masa yang menuntut seorang mahasiswa mampu menentukan sikap dan pilihan, juga mahasiswa merupakan elit masyarakat yang memiliki ciri inteltual yang lebih kompleks dibandingkan dengan kelompok usia mereka yang bukan mahasiswa, ataupun kelompok usia diatas atau dibawah mereka. Adapun ciri inteltualitas tersebut adalah kemampuan mereka untuk menghadapi, mencari, dan memahami cara pemecahan berbagai masalah secara lebih sistematis menurut Azwar (dalam Syahputra, 2006).

Suwardjono (2005) mengemukakan bahwa mahasiswa yang belajar di perguruan tinggi di tuntut tidak hanya memiliki keterampilan teknis tetapi juga memiliki daya dan kerangka pikir serta sikap mental dan kepribadian tertentu, sehingga memiliki wawasanluas dalam menghadapi masalah-masalah dalam dunia nyata (lingkungan kampus maupun lingkungan masyarakat).

Mutadin (2002) juga mengatakan bahwa kesulitan-kesulitan yang sering dialami mahasiswa adalah kesulitan dalam mencari tugas kuliah yang banya, bosan dengan segala tugas yang diberikan dosen, kesulitan menentukan judul skripsi maupun literatur atau bahan bacaan, dan takut menemui dosen pembimbing. Kesulitan ini akhirnya menyebabkan mahasiswa merasa tertekan, sehingga kehilangan motivasi dalam hal belajar. Motivasi dapat dikatakan sebagai pendukung suatu perbuatan, sehingga menyebabkan seseorang memiliki kesiapan untuk melakukan serangkaian kegiatan. Motivasi yang tinggi akan membangkitkan individu untuk melakukan aktifitas tertentu yang lebih fokus dan lebih intensif dalam proses pengerjaan dan sebaliknya, sehingga tinggi rendahnya motivasi di dalam diri mahasisa tersebut 
mampu membangkitkan berapa besar keinginan dalam bertingkah laku atau cepat lambatnya terhadap suatu pekerjaan yang dilakukannya.

Motivasi mengggunakan hasrat yang paling dalam untuk menggerakkan dan menuntun kita untuk menuju sasaran, membantu kita untuk mengambil inisiatif dan bertindak sangat efektif, serta untuk bertahan menghadapi untuk kegagalan dan frustasi menurut Rusyan (dalam Melia, 2010). Aktifitas belajar yang terjadi pada mahasiswa mrupakan sesuatu yang penting. Belajar merupakan suatu aktifitas mental atau psikis ang berlangsung dalam interaksi dengan lingkungan, yang menghasilkan perubahan-perubahan dalam pengtahuan, pemahaman, keterampilan dan nilai sikap (Winkel, 2004). Dengan belajar, mahasiswa dapat mewujudkan apa yang di harapkan karena belajar akan menghasilkan perubahan dalam diri seoranguntuk dapat meraih cita-citanya.

Dalam proses belajar dibutuhkan motivasi karena karena dngan adanya motivasi tersebut belajar dapat menjadi sesuatu yang lebih menyenangkan. Motivasi memiliki peranan yang strategis dalam aktifitas belajar seseorang, tidak ada seorang pun yang belajar tanpa adanya motivasi. Motivasi belajar merupakan keseluruhan daya penggerak psikis didalam diri yang menimbulkan kegiatan belajar, menjamin kelangsungan kegiatan belajar, dan memberikan arah pada kegiatan belajar demi mencapai tujuan (Winkel, 2004).

Pada mahasiswa terdapat motivasi belajar yang berbeda-beda satu sama lainnya. Ada mahasiwa yang memiliki motivasi belajar yang tinggi dan ada juga yang rendah. Mahasiswa yang memiliki motivasi belajar yang tinggi, memiliki keinginan untuk sukses benar-benar berasal dari dirinya sendiri. Mahasiswa tersebut akan bekerja keras dalam situasi bersaing dengan orang lain maupun bekerja sendiri.
Sedangkan mahasiswa yang memiliki motivasi belajar yang rendah cenderung takut gagal dan tidak mau menanggung resiko dalam mencapai prestasi yang tinggi dan terkesan cuek dengan pelajaran yang ada diperkuliahaan. Selanjutnya menurut Ahmadi dan Supriono (2004) individu yang mmiliki motivasi belajar tinggi dikarektiristikkan sebagai berikut: 1 . Setiap ada tugas selalu berusaha menyelesaikannya dengan baik, 2 . Meskipun mendapat nilai yang rendah atau tinggi individu tetap terus belajar, 3. Selalu terus bertanya pada dosen bila ada yang belum diketahui, 4. Tetap terus belajar meskipun tidak ada tugas rumah (PR), 5. Selalu berusha menjadi orang yang pertama dalam menjawab pertannyaan dosen. Sementara itu karakteristik individu yang memiliki motivasi belajar rendah adalah: 1 . Merasa cepat bosan atau cepat letih bila mengerjakan tugas yang diberikan oleh dosen baik tugas dirumah maupun tugas di kampus, 2. Lebih memilih mengerjakan kesenangannya sendiri atau membuat keributan dalam kelas daripada mengerjakan tugas yang disuruh, 3. Selalu mengharapkan bantuan dalam mengerjakan tugas, 4. Malas bertanya tentang hal-hal yang belum diketahuinya, 5. Selalu bersikap biasa-biasa saja bila mendapat nilai yang buruk atau tidak mau berusaha memperbaiki nilai yang buruk.

\section{KAJIAN PUSTAKA}

$\begin{array}{rcll}\text { Mustaqim } & \& & \text { Wahab } & \text { (2003) } \\ \text { mengemukakan } & \text { dalam } & \text { kegiatan } & \text { belajar }\end{array}$ mengajar peranan motivasi sangat diperlukan. Motivasi bagi individu dapat mengembangkan aktifitas dan inisiatif, dapat mengarahkan akan memelihara ketekunan dalam melakukan kegiatan belajar. Dalam kaitannya dengan itu perlu diketahui ada beberapa faktor yang dapat mempengaruhi motivasi belajar, yaitu faktor: 
a. Kematangan: dalam pemberian motivasi , faktor kematangan fisik, sosial dan psikis diperhatikan, karena hal itu dapat mempengaruhi motivasi belajar,

b. Kecerdasan emosional: dengan kecerdasan emosional dapat menciptakan kesenangan dalam belajar, dan menyingkirkan segala ancaman dari halhal yang mengganggu dan menghambat proses belajar.

c. Usaha yang bertujuan: setiap usaha yang dilakukan memiliki tujuan yang ingin dicapai, akan semakin kuat dorongan untuk belajar.

d. Pengetahuan mengenai hasil dalam motivasi: dengan mengetahui hasil belajar, seseorang terdorong untuk lebih giat belajar. Apabila hasil belajar itu mengalami kemajuan, seseorang akan berusaha mempertahankan atau meningkatkan intensitas belajarnya untuk mendapatkan prestasi yang lebih baik dikemudian hari. Prestasi yang rendah menjadikan individu tersebut lebih giat belajar guna memperbaikinya.

e. Penghargaan dan hukuman: pemberian penghargaan itu dapat membangkitkan motivasi seseorang untuk mempelajari atau mengerjakan sesuatu saja. Penghargaan adalah alat, bukan tujuan.

f. Penghargaan tersebut dapat menimbulkan inisiatif, kompetisi dan kemampuan kreatifnya. Hendaknya diperhatikan agar penghargaan ini menjadi tujuan. Tujuan pemberian penghargaan dalam belajar adalah bahawa setelah sesorang menerima penghargaan karena telah melakukan kegiatan belajar yang baik, ia akan melanjtkan kegiatan belajarnya sendiri di luar kelas, sehingga dengan penghargaan yang diterimanya semakin memotivasi untuk terus belajar. Sedabfkan hukuman sebagai reinforcement yang negatif tetapi kalau diberikan secara tepat dan bijak bisa menjadi alat motivasi. g. Partisipasi: partisipasi dapat menimbulkan originalitas, inisiatif dan memberi kesempatan terujudnya ide-ide. Maka perlu untuk memberi kesempatan kepada peseta didik untuk berpatisipasi pada segala kegiatan.

\section{Ciri-ciri yang memiliki motivasi belajar}

Menurut Sadirman (2005) ciri-ciri orang yang memiliki motivasi adalah:

a. Tekun menghadapi tugas

b. Ulet mnghadapi kesulitan

c. Menunjukan minat terhadap berbagai macam-macam masalah

d. Lebih senang bekerja sendiri

e. Tidak mudah bosan pada tugas-tugas rutin

f. Dapat mempertahankan pendapatnya

g. Tidak melepaskan hal-hal yang diyakininya

h. Senang mncari dan memecahkan masalah soal-soal.

Fransen (dalam Syahputra, 2006) mengmukakan ciri-ciri orang yang memiliki motivasi belajar yang tinggi, yaitu:

a. Memiliki rasa ingin tahu

b. Kreatif

c. Ingin mendapat simpati

d. Ingin memperbaiki kegagalan

\section{Ciri-ciri orang yang memiliki kcerdasan emosional}

Stein dalam Golemen (2002) mengemukakan tentang tanda-tanda atau ciri-ciri Kecerdasan emosional secara spesifik , yakni:

a. Ciri-ciri kecerdasan emosional yang tinggi meliputi: Dapat mengekspresikan emosi yang jelas, tidak merasa takut untuk mengekspresikan perasaannya, tidak didominasi oleh perasaan-prasaan negatif, dapat memahami (membaca) komunikasi non verbal, membiarkan perasaan yang dirasakan untuk membimbingnya, berprilaku sesuai 
dengan keinginan bukan dengan keharusan atau ketaatan, dorongan dan tanggung jaab, termotivasi untuk intrinsik, tidak termotivasi kerena kekuatan, memiliki emosi yang fleksibel, peduli dengan perasaan orang lain, dan dapat mengindentifikasikan perasaan secara bersamaan.

b. Ciri-ciri kecerdasan emosional ang rendahmeliputi: Tidak mempunyai rasa tanggung jawab atas perasaan sendiri tetapi menyalahkan orang lain, tidak mengetahui perasaan sendiri sehingga sering menyalahkan orang lain, sering memerintah, sering mengkrintik, berbohong tentang apa yang dia rasakan, suka menyalahkan orang lain, tidak memiliki perasaan, tidak memiliki rasa empati, tidak sensitif perasaan orang lain, kaku dan pesimistik.

\section{Faktor-faktor yang mempengaruhi Kecerdasan Emosional \\ Walgito (1993) mengemukakan} bahwa faktor yang mempengaruhi persepsi kecerdasan emosional dibagi dua faktor, yaitu:

a. Faktor Internal

Faktor internal adalah apa yang ada didalam diri individu yang mempengaruhi kecerdasan emosinya. Faktor internal ini mempunyai dua sumber yaitu segi jasmani dan segi psikologis. Segi jasmani meliputi faktor fisik dan kesehatan individu, apabila fisik dan kesehatan seseorang dapat terganggu dapat dimungkinkan mempengaruhi proses kecerdasan emosionalnya. Sedabfkan segi psikologis mencakup didalamnya, pengalaman, perasaan, kemampuan berpikir, dan motivasi.

b. Faktor Eksternal

Faktor eksternal adalah stimulus dan lingkungan dimana kecerdasan emosional berlangsung. Faktor eksternal meliputi:

1) Stimulus itu sendiri, kejenuhan stimulus merupakan salah satu faktor yang mempengaruhi keberhasilan seseorang dalam memperlalukukan kecerdasan emosional tanpa distorsi.

2) Lingkungan atau situasi khususnya yang melatarbelakangi proses kecerdasan emosional seperti keadaan rumah, kampus maupun keadaan sosial.

\section{Aspek-Aspek Kecerdasan Emosional}

Golemen (2006) membagi aspek kecerdasan emosional menjadi 5 (lima) bagian yaitu:

a. Pengenalan Diri (Self-awarence)

Mampu mengenali emosi dan penyebab pemicu emosi tersebut. Jadi individu mampu mengevaluasi dirinya sendiri dan mendapatkan suatu informasi untuk melakukan suatu tindakan. Ketika seseorang dihadapkan dengan sesuatu kejadian yang menyenangkan atau menyedihkan bisa saja ia sama sekali tidak menyadari apa yang sesungguhnya ia rasakan atau dapat disebut sebagai tidak ada rasanya mengenali emosi diri. Kemampuan untuk memahami perasaan dari waktu ke waktu merupakan hal terpenting bagi pemahaman diri seseorang. Mengenali diri merupakan inti dari kecerdasan emosional, yaitu kesadaran akan perasaan diri sendiri sewaktu perasaan timbul.

b. Penguasaan Diri (self-regulation)

Seseorang mempunyai penguasaan diri yang baik dapat lebih terkontrol dalam membuat tindakan agar lebih berhatihati. Individu juga berusaha untuk tidak impulsif. Akan tetapi perlu diingat akan hal ini bukan berarti bahwa orang tersebut menyembunyikan emosinya 
melainkan memilih untuk tidak diatur oleh emosinya.

c. Motivasi Diri (self-motivasion)

Ketika suatu berjalan tidak sesuai rencana, individu yang memiliki kecerdasan emosional yang tinggi akan mampu memotivasi dirinya sendiri untuk dapat memperbaiki masalah yang dihadapinya. Menggunakan hasrat yang paling dalam untuk menggerakkan dan menuntun diri sendiri menuju sasaran, membantu diri sendiri, inisiatif dan bertindak sangat efektif untuk bertahan menghadapi kegagalan dan frustasi. Orang yang mampu memotivasi dirinya sendiri cenderung lebih produktif dan efktif dalam hal apapun yang mereka kerjakan.

d. Empati (empathy)

Kemampuan untuk mengenali perasaan orang lain dengan merasakan apa yang orang lain rasakan jika dirinya sendiri yang berada pada posisi dirinya sendiri, membutuhkan hubungan saling percaya dan menyearaskan diri dengan bermacam-macam orang .

e. Hubungan yang efektif (effective relationship)

Dengan adanya empat kemampuan tersebut , seseorang dapat berkomunikasi dengan orang lain secara efektif. Kemapuan untuk memecahkan masalah lebih ditekankan dan bukan untuk konfrontasi yang tidak penting yang sebenatnya dapat dihindari. Orang ang mempunyai kecerdasan emosional yang tinggi mempunyai tujuan yang konstruktif dalam pikirannya.

\section{METODOLOGI PENELITIAN Subjek Penelitian}

Subjek dalam penelitian ini ditentukan dengan teknik pengambilan sampel Purposive Random Sampling. Yaitu: Mahasiswa Bimbingan dan
Konseling Universitas Jabal Ghafur 2017/2018, berusia 19-23 tahun, belum bekerja, belum menikah, dan memiliki IPK minimal 3,00. Berdasarkan teknik pengambilan sampel tersebut diperoleh subjek sebanak 79 orang.

\section{Instrumen}

Skala yang digunakan dalam penelitian adalah :

1. Skala Motivasi Belajar

Skala motivasi belajar disusun brdasarkan teori sardiman (2005) meliputi ciri-ciri orang yang memiliki motivasi yakni tekun menghadapi tugas, ulet menghadapi kesulitan, menunjukan minat terhadap berbagai macam-macam masalah, lebih snang bkerja mandiri, tidak cepat bosan pada tugas rutin, dapat mempertahankan pendapatnya, tidak mudah melepaskan hal-hal yang diyakininya dan senang mencari dan memecahkan soal-soal.

2. Skala Kecerdasan Emosional

Skala kecerdasan emosional disusun berdasarkan aspek kecerdasan emosional, menurut Golemen (2006), yaitu meliputi pengenalan diri, penguasaan diri, motivasi diri, empati dan hubungan efektif. Skala ini disusun dengan model skala likert.

\section{Analisis Data dan Hasil Penelitian}

Teknik analisis data yang digunakan dalam penelitian ini adalah Korelasi Produk Moment. Data yang telah diperolah diuji dulu mengenai uji asumsinyayang meeliputi uji normalitas dan uji linieritas hubungan.

\section{Uji Asumsi}

a. Uji Normalitas Sebaran

Uji normalitas sebaran dianalisis dengan menggunakan formula Chi Kuadrat. Berdasarkan analisis tersebut, maka diketahui maka variabel kecerdasan emosional dan motivasi belajar telah 
menyebar mengikuti bentuk kurve normal Ebbing Gauss. Sebagai kriterianya apabila $\mathrm{p}$ lebih besar 0,050 maka sebarannya dinyatakan normal, sebaliknya apabila $\mathrm{p}$ lebih kecil 0,050 sebarannya dinyatakan tidak normal (Hadi dan Pamardiningsih, 2000). Tabel berikut ini merupakan rangkuman hasil perhitungan uji normalitas sebaran

b. Hasil Perhitungan Analisis Korelasi

Product Moment

Berdasarkan hasil perhitungan Analsis Korelasi Product Moment, dapat diketahui bahwa terdapat hubungan positif yang signifikan antara kecerdasan emosional dengan motivasi belajar.

Hasil ini dibuktikan dengan koefisien korelasi $\mathrm{rxy}=0,555 ; \mathrm{p}=0,000$ ( $\mathrm{p}$ lebih kecil 0,050). Artinya semakin tinggi kecerdasan emosional, maka motivasi belajar juga tinggi dan semakin rendah kecerdasan emosional, maka motivasi belajar juga rendah. Berdasarkan hasil analisis ini, maka hipotesis yang telah diajukan dalam pnelitian ini dinyatakan diterima.

\section{Pembahasan}

Berdasarkan hasil perhitungan Analisis Korelasi Product Moment, dapat diketahui bahwa dapat terdapat hubungan positif yang sangat signifikan antara kcerdasan emosional dengan motivasi belajar. Hasil ini dibuktikan dengan koefisien korelasi $\mathrm{rxy}=0,555 ; \mathrm{p}=0,000(\mathrm{p}$ lbh kecil 0,050). Artinya semakin tinggi kcerdasan emosional, maka motivasi belajar juga semakin tinggi dan semakin rendah kecerdasan emosional maka semakin rendah motivasi belajar. Berdasarkan hasil analisis ini, maka hipotesis yang telah diajukan dalam penelitian ini yaitu adanya hubungan positif antara kecerdasan emosional dengan motivasi belajar pada mahasisiswa FKIP Bimbingan dan Konseling Universitas Jabal Ghafur dengan asumsi bahwa semakin tinggi kecerdasan emosional pada mahasiswa maka semakin tinggi motivasi belajar, sebaliknya semakin rendah kecerdasan emosional pada mahasiswa maka semakin rendah pula motivasi belajarnya, maka hipotesisnya dinyatakan diterima.

Hasil penelitian lainnya, mahasiswa FKIP Bimbingan dan Konseling Universitas Jabal Ghafur ternyata memiliki kecerdasan emosional yang tergolong tinggi, sebab nilai rerata empirik $(97,354)$ selisihnya dengan nilai rerata hipotetiknya $(77,5)$ melebihi bilangan SD atau SB yang sebesar 8,184. Dalam motivasi belajar, para mahasiwsa tergolong tinggi, sebab nilai rerata empirik $(135,658)$ selisihnya dengan rerata hipotetik (110)melebihi bilangan SD atau SB yang sebesar 11,613.

\section{Penutup}

Berdasarkan hasil-hasil yang telah diproleh dalam pnelitian ini, maka dapat disimpulkan hal-hal sebagai berikut:

Terdapat hubungan positif yang sangat signifikan antara kecerdasan emosional dengan motivasi belajar. Hasil ini dibuktikan dengan koefisien korelasi $\mathrm{rxy}=0,555 ; \mathrm{p}=1 \mathrm{bh}$ kecil 0,050 ). Artinya semakin tinggi kecerdasan emosional pada mahasiswa maka semakin tinggi motivasi belajar, sebaliknya semakin rendah kecerdasan emosional pada mahasiswa maka semakin rendah pula motivasi belajarnya.

Kecerdasan emosional yang dimiliki individu mempengaruhi tinggi rendahnyan motivasi belajar sebesar 30, $8 \%$. Berdasarkan hasil ini diketahui pula bahwa motivasi belajar dipengaruhi oleh faktor atau variabel lain sebesar $69,2 \%$. Ini berarti bahwa faktor atau variabel lain yang perannya dalam meningkatkan motivasi dan faktor atau variabel lain yang perannya dalam meningkatkan motivasi belajar dan faktor atau variabel lain tersebut dalam 
penelitian ini tidak terlihat, diantaranya adalah usaha untuk meningkatkan motivasi belajar mereka, pengetahuan mengenai hasil dalam motivasi, penghargaan dan hukuman, serta partisipasi untuk mengembangkan ide-ide pada segala kegiatan mereka dan juga faktor stimulus mereka dalam belajar, faktor metode belajar dan juga faktor individual mereka sendiri.

Mahasiswa FKIP Bimbingan dan Konseling Universitas Jabal Ghafur ternyata memiliki kecerdasan emosional yang tergolong tinggi, sebab nilai rerata empirik $(97,354)$ selisihnya dengan nilai rerata hipotetiknya $(77,5)$ melebihi bilangan SD atau SB yang sebesar 8,184. Dalam motivasi belajar, para mahasiwsa tergolong tinggi, sebab nilai rerata empirik $(135,658)$ selisihnya dengan rerata hipotetik (110)melebihi bilangan SD atau SB yang sebesar 11,613.

\section{DAFTAR PUSTAKA}

Ahmadi, A. \& Supriono,W. 2004

$$
\begin{aligned}
& \text { Psiklogi Belajar. Jakarta: PT. } \\
& \text { Rineka Cipta }
\end{aligned}
$$

Ariunto, S. 1997. Prosedur Penelitian Suatu Pendeketan Praktik. Jakarta:PT. Rineka Cipta.

Atinson, R. L. 2008. Pengantar Psikologi. Bandung: Pustaka Setia.

Azwar, S. 2004. Penyusunan Skala Psikologi. Jakarta: Erlangga.

Buku Pedoman Mahasisa UMA 2010/2011 Djamarah, S. B. 2002.Psikologi Belajar. Jakarta: Rineka Cipta.

Goleman, D. 2002. Kecerdasan Emosional: Mengapa Emosional Lebih tinggi dari IQ. Jakarta: Gramedia Pustaka
-----------, 2006. Emosional Inteligence (cetakan Ke 16). Jakarta: Gramedia Pustaka.

Hadi, S. 2004. Statistik jilid I. Yogyakarta: Andi

Hadi, S. 2004. Statistik Jilid III. Yogyakarta: Andi

Melia, E. 2010. Hubungan Antara Konformitas dengan Motivasi Belajar SMP Istiqlal Deli Tua. Skripsi. Tidak diterbitkan. Medan. Univeritas Medan Area

Mustaqim \& Wahab, A. 2003. Psikologi Pendidikan. Semarang: PT. Rineka Cipta.

Mutadin, Z. 2007. Mengenal Kecerdasan Remaja (www.e-psikologi.com), diakses 11/03/18

Santrock, J. W .2004. Perkembangan Remaja Edisi Keenam, Jakarta: Penerbit: Erlangga.

Sandhawati, S. 2007. Hubungan Antara Kecerdasan Emosional dengan Motivasi Belajar Mahasiswa D IV Kebidanan Jalur Transfer FK UNS . Abstrak.

Sardiman. 2005. Interaksi \& Motivasi Belajar. Jakarta: PT Raja Gravindo Persada.

Sugiono. 2009. Statistika Untuk Penelitian. Bandung: Alfabet

Surya, H. 2011. Strategi Jitu Mencapai Kesuksesan Belajar. Jakarta. Elex Media Komputindo. 